\section{Efficacy of Dikegulac Sodium Applied to Pruned and Unpruned 'Limelight' Hydrangea Grown at Two Locations in the Southeastern United States}

\author{
Diana R. Cochran ${ }^{1}$, Amy Fulcher ${ }^{1,3}$, and Guihong $\mathrm{Bi}^{2}$
}

ADDITIONAL INDEX wORDs. branch architecture, growth retardant, hand pruning, plant growth regulator, plant quality

SumMary. Pruning is commonly performed during production of nursery crops to produce symmetrical, compact plants that are pleasing to the consumer's eye. To achieve the desired results, nursery growers hand prune or apply plant growth regulators (PGRs). However, hand pruning is expensive and is not always effective, and efficacy of PGRs can depend on cultural practices, environmental conditions, irrigation, cultivar, and rate. Therefore, the objective of these experiments was to evaluate the effect of dikegulac sodium applied to pruned or unpruned 'Limelight' hardy hydrangea (Hydrangea paniculata). Plants were grown at two locations, Tennessee (TN) and Mississippi (MS). The pruned treatment consisted of hand pruning, leaving three nodes followed by applications of dikegulac sodium $(400$, 800 , or $1600 \mathrm{ppm}$ ). Applications of dikegulac sodium to pruned or unpruned plants were made the same day using a carbon dioxide backpack sprayer. There were two additional control treatments: hand-pruned untreated (hand-pruned) and unpruned untreated (untreated). Plants were grown outdoors under full sun in TN and under $40 \%$ shade in MS. Data were collected at the close of the experiment on the number of branches over 1 inch, final growth index (FGI), floral attributes, branch symmetry, and phytotoxicity. At both locations, pruned and unpruned plants treated with 800 or 1600 ppm dikegulac sodium had more branches than the hand-pruned and unpruned plants. Flower number and size tended to be greater for unpruned plants than pruned plants. Phytotoxicity was observed at 2 and 6 weeks after treatment (WAT). For plants grown in TN, symptoms were more pronounced on plants following treatment with 800 (pruned plants) and $1600 \mathrm{ppm}$ (pruned and unpruned) dikegulac sodium compared with the untreated plants. There were no visible phytotoxicity symptoms at 6 WAT for plants grown in MS, regardless of treatment.

$\mathrm{H}$ ydrangeas (Hydrangea sp.) are extremely popular and account for an estimated $\$ 73$ million in U.S. sales annually [U.S. Department of Agriculture (USDA), 2009]. With an estimated 23 Hydrangea species worldwide (U.S. National Arboretum, 2005), there are

The authors gratefully acknowledge the financial support of the IR-4 program.

We acknowledge Whitney Yeary, Marisol BenitezRamirez, Phil Flanagan, Ethan Hagen, Andrea Menendez, and S. Evan Wilson for technical assistance and Harrell's LLC for fertilizer. We thank Dr. Eugene Blythe and Dr. Brian Jackson for their critical review of this manuscript prior to submission.

Mention of a trademark, proprietary product, or vendor does not constitute a guarantee or warrantee of the product and does not imply its approval to the exclusion of other products or vendors that also may be suitable.

${ }^{1}$ Department of Plant Sciences, University of Tennessee, Knoxville, TN 37996

${ }^{2}$ Department of Plant and Soil Sciences, Mississippi State University's Truck Crops Branch Experiment Station, Crystal Springs, MS 39059

${ }^{3}$ Corresponding author. E-mail: afulcher@utk.edu. only five species [florist hydrangea (H. macrophylla), hardy hydrangea (H. paniculata), smooth hydrangea $(H$. arborescens), oakleaf hydrangea $(H$. quercifolia), climbing hydrangea (H. anomala ssp. petiolaris)] generally available in the United States. The popularity of hydrangeas among consumers can be linked to the large, showy inflorescences, remontant blooming of colors, including blue.

Pruning is a common practice in nursery production to improve overall shape and reduce plant size, encourage some selections, and range of bloom branching, and influence flower development, all of which have been reported by retail consumers as important characteristics of plant quality (Glasgow, 1999). However, hand pinching or pruning does not always yield optimal branching (Hester et al., 2013; Starman, 1991). Starman (1991) reported fewer primary branches on manually pinched 'Aurore', 'Celerio', 'Eurema', 'Isopa', 'Marumba', 'Morio', 'Patula', 'Phoebis', 'Selenia', and 'Sesia' impatiens (Impatiens hybrids) compared with no pinching. Hand pinching also affects reproductive development. For instance, manually pruned Little Lime $^{\mathrm{TM}}$ hardy hydrangea had reduced flower number compared with unpruned plants (Cochran and Fulcher, 2013). Still, growers continue to rely on hand pinching or pruning to control growth or modify plant architecture during production.

Hand pinching is not only inefficient, but it can be labor intensive and represents a significant cost of production (Holland et al., 2007). Therefore, the use of PGRs to control height, promote symmetrical branching, and/or increase flower production could be a better alternative to manual pruning. PGRs have proven to be effective in improving compactness (Hammond et al., 2007), increasing branch number (Holland et al., 2007), and increasing flower number (Abdelgadir et al., 2010). However, since the introduction of chemical pinching agents in the 1960s (Cathey et al., 1966), there has been an ongoing lack of consistency across plant species. Cohen (1978) reported $4400 \mathrm{ppm}$ dikegulac sodium increased mean number of shoots of 'Formosa' indica azalea ( $R$ hododendron indicum) compared with manually pinching yet there was no difference in shoot number of 'Hexe' indica azalea (Rhododendron indicum) 10 WAT. Auer et al. (1992) concluded that two petunia hybrid (Petunia $\times$ bybrida) lines differed in absorption of benzyladenine by leaf explants. Bailey and Clark (1992)

\begin{tabular}{llll}
\hline $\begin{array}{l}\text { Units } \\
\text { To convert U.S. to SI, } \\
\text { multiply by }\end{array}$ & U.S. unit & SI unit & $\begin{array}{l}\text { To convert SI to U.S., } \\
\text { multiply by }\end{array}$ \\
\hline 3.7854 & gal & $\mathrm{L}$ & 0.2642 \\
2.54 & inch(es) & $\mathrm{cm}$ & 0.3937 \\
6.4516 & inch & $\mathrm{cm}^{2}$ & 0.1550 \\
1 & $\mathrm{ppm}$ & $\mathrm{mg} \cdot \mathrm{L}^{-1}$ & 1 \\
6.8948 & $\mathrm{psi}$ & $\mathrm{kPa}$ & 0.1450 \\
$\left({ }^{\circ} \mathrm{F}-32\right) \div 1.8$ & ${ }^{\circ} \mathrm{F}$ & ${ }^{\circ} \mathrm{C}$ & $\left({ }^{\circ} \mathrm{C} \times 1.8\right)+32$
\end{tabular}


reported one application of daminozide increased inflorescence size of 'Schenkenburg' florist hydrangea, but had no effect on six other florist hydrangea cultivars (Böttstein, Enziandom, Kasteln, Mathilde Cütges, Merritt's Supreme, and Red Star). Norcini et al. (1994) evaluated 'Mauna Kea White' bougainvillea (Bougainvillea glabra) and 'Raspberry Ice', 'Royal Purple', 'Summer Snow', and 'Temple Fire' bougainvillea (Bougainvillea buttiana), but only 'Temple Fire' had more open inflorescences per branch following two applications (at 0 and 4 weeks) of dikegulac sodium. With these varied responses, PGRs should be tested on cultivars to determine their efficacy. Therefore, the objective of these experiments was to evaluate the effect of dikegulac sodium applied to pruned and unpruned 'Limelight' hydrangea.

\section{Materials and methods}

Plant material and culture. Experiments were conducted outdoors at two locations during Summer/Fall 2012: at the University of Tennessee's Nursery Research Complex, Knoxville, TN (lat. $35^{\circ} 56^{\prime} 39.15^{\prime \prime} \mathrm{N}$, long. $\left.83^{\circ} 56^{\prime} 16.73^{\prime \prime} \mathrm{W}\right)$ and at Mississippi State University's Truck Crops Branch Experiment Station, Crystal Springs, MS (lat. $31^{\circ} 57^{\prime} 46.87^{\prime \prime} \mathrm{N}$, long. $\left.90^{\circ} 22^{\prime} 51.77^{\prime \prime} \mathrm{W}\right)$. The experiment was initiated on 8 May 2012 (TN) and 18 May 2012 (MS) by potting 'Limelight' (2.25 inch pots; Spring Meadows Nursery, Grand Haven, MI) into 3-gal containers filled with $85 \%$ pine bark : $15 \%$ peat. One week after potting [14 May 2012 (TN) and 25 May 2012 (MS)], plants were top-dressed with $19 \mathrm{~N}-1.7 \mathrm{P}-6.6 \mathrm{~K}, 5$ to 6 -month, controlled-release fertilizer with minors (Harrell's, Lakeland, FL) at $64 \mathrm{~g}$ per container (high label rate). Initial irrigation in TN was once per day for $20 \mathrm{~min}$ at 8:00 $\mathrm{AM}$ and, after 6 weeks, irrigation was increased to three times per day (8:00 AM, 1:00 PM, and 4:00 PM) for 15 min per application using 3.2 gal/h pressure-compensating spray stakes (PCNL Spray Stake; Netafim, Fresno, CA). Irrigation in MS was once per day (8:00 AM) for $20 \mathrm{~min}$ and, after 6 weeks, was increased to twice per day (8:00 $\mathrm{AM}$ and 2:00 $\mathrm{PM}$ ) for $20 \mathrm{~min}$ per application using $3.2 \mathrm{gal} / \mathrm{h}$ PCNL spray stakes.

Plant growth Regulator APPliCATION. On 23 May 2012, 'Limelight' plants were divided into two branching treatment groups: pruned or unpruned. Pruned plants were hand-pruned (cuts were made on semiwoody stems) on 23 May 2012 (both locations), leaving three nodes and allowed to grow for $\approx 3$ weeks. On 12 June 2012, dikegulac sodium (Augeo; OHP, Mainland, PA) was applied to pruned and unpruned plants at both locations at a rate of 400,800 , or 1600 ppm according to the IR-4 protocol (IR-4 Project, 2012). There were two control treatments: a handpruned leaving three nodes (no water) and a watered unpruned (untreated). Foliar applications were made to runoff using a carbon dioxide backpack sprayer (30 psi, TeeJet 8003 e flat fan nozzle; Spraying Systems, Wheaton, IL) at both locations. Plants were grown outdoors under standard production conditions appropriate for each location: full sun in TN and $40 \%$ shade in MS. Data were collected at 16 WAT on the number of branches over 1 inch in length, FGI $=$ (height + width + perpendicular width $) \div 3$, and at 18 WAT for floral attributes. Floral data included flower number, flower length (length from apex to basal end of panicle), then flower width (measured at basal end of panicle) to determine flower index. Flower index was determined using the formula for total surface area of a cone $\{(\pi \times$ half-width $\left.{ }^{2}\right)+[(\pi \times$ half-width $) \times$ $\sqrt{ }\left(\right.$ half-width $^{2}+$ height $\left.\left.\left.^{2}\right)\right]\right\}$, using flower length and flower half-width (half-width $=0.5 \times$ flower width) to account for the overall shape of the flower (panicle). Additionally, branch symmetry, a measure of plant quality, was assessed by determining overall plant architecture (plant size, density, and branch symmetry) and whether the substrate surface was covered by the foliage or exposed. This quality rating was determined at the end of the experiment with a 1 to 7 scale, where 1 = significantly worse than untreated, $2=$ moderately worse than untreated, $3=$ slightly worse than untreated, $4=$ no difference from untreated, $5=$ slightly better than untreated, $6=$ moderately better than untreated, $7=$ significantly better than untreated. Plants were evaluated at 2 and 6 WAT for phytotoxicity symptoms on a 0 to 10 visual scale; 0 representing no injury and 10 representing complete kill.

EXPERIMENTAL DESIGN AND ANALYSIS. Experiments were conducted using a completely randomized design with 16 (TN) and 12 (MS) single pot replications. Data were analyzed using linear models with the GLIMMIX procedure of SAS (version 9.2; SAS Institute, Cary, NC). Treatment differences for branch number, FGI, and floral attributes were determined using the LSMEANS statement according to the Tukey-Kramer method, $\alpha=$ 0.05. Square root transformations were applied to branch number and phytotoxicity data for a more normal distribution and untransformed data are reported. Branch symmetry was assessed by comparing plants with the untreated controls; therefore, Dunnett's multiple comparison procedure was used to analyze branch symmetry, $\alpha=0.05$.

\section{Results}

Experiments were conducted in USDA hardiness zones: 7a (TN) and 8a (MS) (USDA, 2012). Average air temperature for University of Tennessee's Nursery Research Complex (TN) was $26.8 / 14.6{ }^{\circ} \mathrm{C}$ (day/night) $\left[40.6 /-1.7^{\circ} \mathrm{C}(\right.$ maximum $/$ minimum $\left.)\right]$ (Fig. 1) (Leib, 2012). Average air temperature for Mississippi State's Truck Crops Branch Experiment Station (MS) was $29.8 / 17.0{ }^{\circ} \mathrm{C}$ (day/night) $\left[38.3 / 0{ }^{\circ} \mathrm{C}\right.$ (maximum/ minimum)] (National Oceanic and Atmospheric Administration, 2012). Air temperature for $\mathrm{TN}$ was recorded at the University of Tennessee's Trial Garden, adjacent to the research complex and air temperature for Mississippi State's Truck Crops Branch Experiment Station was recorded on the station.

At both locations, hand-pruned and untreated plants had fewer branches than plants treated with dikegulac sodium at 800 or 1600 ppm (pruned or unpruned plants) (Table 1). For example, hand-pruned and untreated plants grown in TN had 24.7 (45\%) and 21.5 (39\%) fewer branches than pruned plants treated with 800 ppm dikegulac sodium and 15.7 (34\%) and $12.5(27 \%)$ fewer branches than unpruned plants treated with $800 \mathrm{ppm}$ dikegulac sodium. Hand-pruned and untreated plants grown in MS had $88.7(74 \%)$ and $96.9(81 \%)$ fewer branches than pruned plants treated with 800 dikegulac sodium and 74.9 (71\%) and 83.1 (79\%) fewer branches than unpruned plants treated with 800 dikegulac sodium. At both locations, FGI was similar among all treatments. 




Fig. 1. Average daily maximum (TN Day) and minimum (TN Night) air temperatures recorded at the University of Tennessee Trial Gardens, Knoxville, Tennessee [TN (lat. $35^{\circ} 56^{\prime} 39.15^{\prime \prime} \mathrm{N}$, long. $83^{\circ} 56^{\prime} 16.73^{\prime \prime} \mathrm{W}$ )] and average daily maximum (MS Day) and minimum (MS night) air temperatures recorded at the Mississippi State, Truck Crops Branch Experiment Station, Crystal Springs, Mississippi [MS (lat. $31^{\circ} 57^{\prime} 46.87^{\prime \prime} \mathrm{N}$, long. $\left.\left.90^{\circ} 22^{\prime} 51.77^{\prime \prime} \mathrm{W}\right)\right] ;\left(1.8 \times{ }^{\circ} \mathrm{C}\right)+$ $32={ }^{\circ} \mathbf{F}$.
Branch symmetry was affected by pruning and rate of dikegulac sodium. Plants grown in TN treated with 400 ppm dikegulac sodium applied to pruned plants were rated as having moderately better $[6.4(P=0.0007)]$ branch symmetry than untreated plants (4.0) (Fig. 2); whereas, branch symmetry for unpruned plants treated with 400 ppm dikegulac sodium was not different $[4.6(P=0.8896)]$ from the untreated plants (4.0). Moreover, pruned plants treated with 800 ppm dikegulac sodium were rated as having significantly better $[6.9(P=0.0001)]$ branch symmetry to the untreated plants compared with a moderately better $[6.2(P=0.0015)]$ branch symmetry rating when dikegulac sodium (800 ppm) was applied to unpruned plants. Plants treated with 1600 ppm dikegulac sodium (pruned or unpruned) were rated as having significantly better $[7.0(P=0.0001)]$ branch symmetry than the untreated plants. Regardless of branching treatment, plants grown in MS had a greater branch symmetry rating than the

Table 1. Branch number and growth of pruned and unpruned 'Limelight' hardy hydrangea affected by application of dikegulac sodium, evaluated 16 weeks after treatment at two locations: the University of Tennessee, Knoxville, Tennessee [TN $(n=128)]$ and Mississippi State University, Truck Crops Branch Experiment Station, Crystal Springs, Mississippi [MS $(n=96)]$.



$P$ value $\quad 0.0001$
0.1817

\section{$M S$}

\begin{tabular}{|c|c|c|c|c|}
\hline Hand-pruned & - & Pruned & $30.5 \mathrm{~d}$ & 109.2 \\
\hline Dikegulac sodium & 400 & Pruned & $75.9 \mathrm{bc}$ & 101.6 \\
\hline Dikegulac sodium & 800 & Pruned & $119.2 \mathrm{a}$ & 94.7 \\
\hline Dikegulac sodium & 1600 & Pruned & $137.8 \mathrm{a}$ & 99.2 \\
\hline Untreated & - & Unpruned & $22.3 \mathrm{~d}$ & 97.9 \\
\hline Dikegulac sodium & 400 & Unpruned & $45.2 \mathrm{~cd}$ & 103.4 \\
\hline Dikegulac sodium & 800 & Unpruned & $105.4 \mathrm{ab}$ & 102.5 \\
\hline Dikegulac sodium & 1600 & Unpruned & $105.3 \mathrm{ab}$ & 102.5 \\
\hline
\end{tabular}

$P$ value

0.0001

${ }^{\mathrm{z}}$ Treatments were applied 12 June 2012

${ }^{\mathrm{y}} \mathrm{l} \mathrm{ppm}=1 \mathrm{mg} \cdot \mathrm{L}^{-1}$

${ }^{x}$ Branching treatment: dikegulac sodium was applied to either pruned (hand-pruned, leaving three nodes) or unpruned plants.

"Final branch number of branches greater than 1 inch $(2.54 \mathrm{~cm})$.

${ }^{\vee}$ FGI: final growth indices $=($ height + width + perpendicular width $) \div 3 ; 1 \mathrm{~cm}=0.3937$ inch .

"Means with the same letters within columns are not statistically different according to Tukey-Kramer studentized range test, $\alpha=0.05$. 


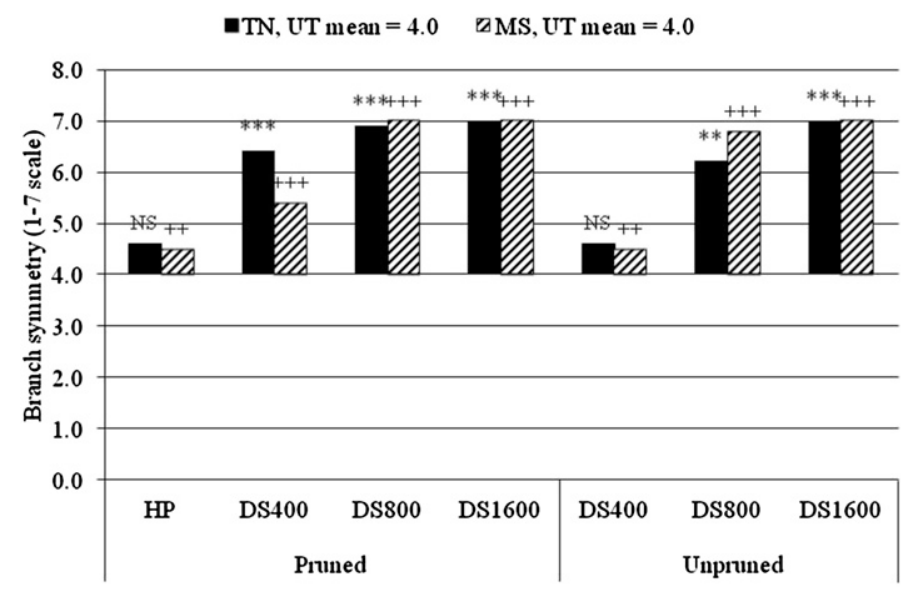

Fig. 2. Branch symmetry of 'Limelight' hardy hydrangea affected by branching treatment (pruned and unpruned) and dikegulac sodium (DS) application evaluated 16 weeks after treatment at two locations: University of Tennessee, Knoxville, Tennessee (TN) and Mississippi State University, Truck Crops Branch Experiment Station, Crystal Springs, Mississippi (MS). The manually pruned branching treatment consisted of hand pruning 'Limelight' hardy hydrangea on 23 May 2012, leaving three nodes, and then applying DS. Application of DS was made on 12 June 2012 for all treatments at a rate of 400,800 , or $1600 \mathrm{ppm}$ $\left(\mathrm{mg} \cdot \mathrm{L}^{-1}\right)$. There were two additional control treatments; a hand-pruned (HP) leaving three nodes and a watered unpruned (UT), applied the same day as the plant growth regulator (PGR) application. Visually rated on a $1-7$ scale: 1 = significantly worse than untreated, 2 = moderately worse than untreated, $3=$ slightly worse than untreated, 4 = no difference from untreated, $5=$ slightly better than untreated, $6=$ moderately better than untreated, $7=$ significantly better than untreated. $N S$, * *, *** , nonsignificant or significant based on Dunnett's multiple comparison test, $P \leq 0.01$ or 0.001 ( $\mathrm{TN} ; n=128$ ) and,+++++ , significant based on Dunnett's multiple comparison test, $P \leq 0.01$ or 0.001 (MS; $n=96)$.

untreated plants. Hand-pruned plants were rated as having slightly better $[4.5(P=0.0041)]$ branch symmetry than the untreated. This was similar to applying the lower rate of dikegulac sodium (400 ppm) to unpruned plants, which resulted in a slightly better $[4.5(P=0.0041)]$ branch symmetry rating compared with the untreated. Whereas, 800 and $1600 \mathrm{ppm}$ dikegulac sodium applied to pruned and unpruned plants resulted in a significantly better $[7.0(P=0.0001) ; 7.0$ $(P=0.0001) ; 6.8(P=0.0001) ; 7.0$ $(P=0.0001)$, respectively] branch symmetry rating compared with the untreated.

Hand-pruned plants tended to have fewer flowers than unpruned plants (Table 2). For example, in TN, pruned plants treated with $400 \mathrm{ppm}$ dikegulac sodium had 3.1 (89\%) fewer flowers than unpruned plants treated with $400 \mathrm{ppm}$ dikegulac sodium. Applying 800 or $1600 \mathrm{ppm}$ dikegulac sodium to pruned plants resulted in no flowers. Flowers were shorter in all branching treatments compared with untreated plants, with the exception of flowers on the unpruned plants treated with $400 \mathrm{ppm}$ dikegulac sodium, in TN. Additionally, flower length tended to decrease as rate of dikegulac sodium increased. For example, flowers of unpruned plants in TN treated with $400 \mathrm{ppm}$ dikegulac sodium were $6.0 \mathrm{~cm} \mathrm{(105 \% )} \mathrm{and} 8.8 \mathrm{~cm} \mathrm{(303 \% )}$ longer than flowers on unpruned plants treated with 800 and 1600 ppm dikegulac sodium. Similarly, flowers on untreated plants and unpruned plants treated with 400 ppm dikegulac sodium were greater in width and overall size (flower index) compared with flowers in all other treatments (TN). In MS, hand-pruned, pruned plus treatment with dikegulac sodium (400, 800 , and $1600 \mathrm{ppm}$ ), and untreated plants had fewer flowers than unpruned plants treated with 800 and 1600 ppm dikegulac sodium. Flowers were shorter on pruned and unpruned plants treated with 800 and $1600 \mathrm{ppm}$ compared with untreated and unpruned plants treated with $400 \mathrm{ppm}$ in MS. Flower length of unpruned plants treated with $400 \mathrm{ppm}$ dikegulac sodium were $10.1 \mathrm{~cm}(66 \%)$ and
$9.3 \mathrm{~cm}(58 \%)$ longer than flowers on unpruned plants treated with 800 and $1600 \mathrm{ppm}$ dikegulac sodium in MS. Untreated and unpruned plants treated with $400 \mathrm{ppm}$ had greater flower width than unpruned and pruned plants treated with 800 and 1600 ppm dikegulac sodium. Floral indices were greater for untreated and unpruned plants treated with $400 \mathrm{ppm}$ compared with all other treatments, with the exception of hand-pruned plants. Additionally, hand-pruned plants had greater floral indices than pruned plants treated with 800 and 1600 ppm dikegulac sodium.

All applications of dikegulac sodium exhibited phytotoxicity compared with the hand-pruned and untreated plants at 2 WAT (TN and MS) (Table 3). Symptoms were more pronounced on new growth with complete bleaching of the first, second, and sometimes third distal sets of leaves, and interveinal chlorosis on the following one to two sets of leaves in TN. At 6 WAT, phytotoxicity ratings were higher for the pruned (1600 ppm dikegulac sodium) and unpruned (800 and $1600 \mathrm{ppm}$ dikegulac sodium) plants compared with untreated plants in TN. There was no phytotoxicity at 6 WAT for plants in MS.

\section{Discussion}

At both locations, dikegulac sodium (800 and 1600 ppm) consistently improved branching compared with the hand-pruned and untreated plants. Branching did not increase when rate increased from 800 to $1600 \mathrm{ppm}$; therefore, there was no advantage to applying $1600 \mathrm{ppm}$. Average branch number of the handpruned plants was relatively similar at the two locations, $30.4(\mathrm{TN})$ and 30.5 (MS), and there was only an 11.3 difference in average branch number for the untreated controls between the two locations. Although the control treatments (hand-pruned and untreated) had similar branch number, the magnitude of response to PGR treatment differed between the two locations.

In TN, application of $800 \mathrm{ppm}$ dikegulac sodium to unpruned plants had $15.7(52 \%)$ and $12.5(37 \%)$ more branches than hand-pruned and untreated controls; whereas, in MS application of $800 \mathrm{ppm}$ dikegulac sodium to unpruned plants had $74.9(246 \%)$ and $83.1(373 \%)$ more branches than 
Table 2. Floral development of pruned and unpruned 'Limelight' hardy hydrangea affected by application of dikegulac sodium, evaluated 18 weeks after treatment at two locations: University of Tennessee, Knoxville, Tennessee [TN $(n=128)$ ] and Mississippi State University, Truck Crops Branch Experiment Station, Crystal Springs, Mississippi [MS $(n=96)]$.

\begin{tabular}{|c|c|c|c|c|c|c|}
\hline Treatment $^{z}$ & Rate $^{\mathrm{y}}$ & $\begin{array}{l}\text { Branching } \\
\text { treatment }^{\mathrm{x}}\end{array}$ & $\begin{array}{c}\text { Flowers } \\
\text { (no.) }\end{array}$ & $\begin{array}{l}\text { Flower length } \\
(\mathrm{cm})^{\mathrm{w}}\end{array}$ & $\begin{array}{l}\text { Flower width } \\
(\mathrm{cm})^{\mathrm{v}}\end{array}$ & $\begin{array}{c}\text { Flower index } \\
\left(\mathrm{cm}^{2}\right)^{\mathrm{u}}\end{array}$ \\
\hline \multicolumn{7}{|c|}{$T N$} \\
\hline Hand-pruned & - & Pruned & $0.8 \mathrm{bc}$ & $4.2 \mathrm{bc}$ & $4.6 \mathrm{bc}$ & $162.7 \mathrm{~b}$ \\
\hline Dikegulac sodium & 400 & Pruned & $0.4 \mathrm{c}$ & $2.5 \mathrm{bc}$ & $2.6 \mathrm{bc}$ & $91.9 \mathrm{~b}$ \\
\hline Dikegulac sodium & 800 & Pruned & $0.0 \mathrm{c}$ & $0.0 \mathrm{c}$ & $0.0 \mathrm{c}$ & $0.0 \mathrm{~b}$ \\
\hline Dikegulac sodium & 1600 & Pruned & $0.0 \mathrm{c}$ & $0.0 \mathrm{c}$ & $0.0 \mathrm{~b}$ & $0.0 \mathrm{~b}$ \\
\hline Dikegulac sodium & 800 & Unpruned & $1.9 \mathrm{abc}$ & $5.7 \mathrm{~b}$ & $6.1 \mathrm{~b}$ & $181.8 \mathrm{~b}$ \\
\hline \multirow[t]{2}{*}{ Dikegulac sodium } & 1600 & Unpruned & $0.7 \mathrm{bc}$ & $2.9 \mathrm{bc}$ & $3.1 \mathrm{bc}$ & $88.4 \mathrm{~b}$ \\
\hline & & $P$ value & 0.0001 & 0.0001 & 0.0001 & 0.0001 \\
\hline
\end{tabular}

\begin{tabular}{|c|c|c|c|c|c|c|}
\hline \multicolumn{7}{|c|}{$M S$} \\
\hline Hand-pruned & - & Pruned & $9.7 \mathrm{c}$ & $21.4 \mathrm{abc}$ & $18.6 \mathrm{abc}$ & $978.3 \mathrm{ab}$ \\
\hline Dikegulac sodium & 800 & Pruned & $6.6 \mathrm{c}$ & $14.6 \mathrm{c}$ & $14.0 \mathrm{~d}$ & $525.0 \mathrm{c}$ \\
\hline Water & - & Unpruned & $8.8 \mathrm{c}$ & $23.6 \mathrm{ab}$ & $21.9 \mathrm{a}$ & $1302.0 \mathrm{a}$ \\
\hline Dikegulac sodium & 400 & Unpruned & $13.6 \mathrm{bc}$ & $25.3 \mathrm{a}$ & $20.8 \mathrm{ab}$ & $1273.0 \mathrm{a}$ \\
\hline Dikegulac sodium & 800 & Unpruned & $19.5 \mathrm{ab}$ & $15.2 \mathrm{c}$ & $16.7 \mathrm{~cd}$ & $676.4 \mathrm{bc}$ \\
\hline & & $P$ value & 0.0001 & 0.0001 & 0.0001 & 0.0001 \\
\hline
\end{tabular}

${ }^{2}$ Treatments were applied 12 June 2012.

${ }^{\mathrm{y}} \mathrm{l} \mathrm{ppm}=1 \mathrm{mg} \cdot \mathrm{L}^{-1}$

${ }^{x}$ Branching treatment: dikegulac sodium was applied to either pruned (hand-pruned, leaving three nodes) or unpruned plants.

"Flower length: determined from apical to basal end of panicle; $1 \mathrm{~cm}=0.3937$ inch.

"Flower width: determined at basal end of panicle.

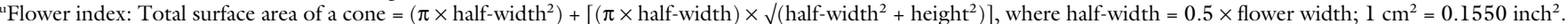

${ }^{t}$ Means with the same letters within columns are not statistically different according to Tukey-Kramer studentized range test, $\alpha=0.05$.

Table 3. Phytotoxicity of pruned and unpruned 'Limelight' hardy hydrangea assessed 2 and 6 weeks after treatment (WAT) with dikegulac sodium at two locations: University of Tennessee, Knoxville, Tennessee [TN $(n=128)]$ and Mississippi State University, Truck Crops Branch Experiment Station, Crystal Springs, Mississippi [MS $(n=96)]$.

\begin{tabular}{|c|c|c|c|c|c|c|}
\hline \multirow[b]{3}{*}{ Treatment $^{\mathrm{z}}$} & \multirow[b]{3}{*}{ Rate $(\mathrm{ppm})^{\mathrm{y}}$} & \multirow[b]{3}{*}{ Branching treatment $\mathrm{t}^{\mathrm{x}}$} & \multicolumn{2}{|c|}{$T N$} & \multicolumn{2}{|c|}{$M S$} \\
\hline & & & \multicolumn{4}{|c|}{ Phytotoxicity (0-10 scale $)^{\mathrm{w}}$} \\
\hline & & & 2 WAT & $6 \mathrm{WAT}$ & 2 WAT & $6 \mathrm{WAT}$ \\
\hline Dikegulac sodium & 400 & Pruned & $2.6 \mathrm{ab}$ & $0.4 \mathrm{~d}$ & $1.8 \mathrm{c}$ & 0.0 \\
\hline Dikegulac sodium & 800 & Pruned & $2.7 \mathrm{ab}$ & $0.2 \mathrm{~d}$ & $2.4 \mathrm{ab}$ & 0.0 \\
\hline Dikegulac sodium & 1600 & Pruned & $2.9 \mathrm{a}$ & $2.0 \mathrm{ab}$ & $2.8 \mathrm{a}$ & 0.0 \\
\hline Dikegulac sodium & 800 & Unpruned & $2.4 \mathrm{ab}$ & $2.6 \mathrm{a}$ & $2.2 \mathrm{bc}$ & 0.0 \\
\hline \multirow[t]{2}{*}{ Dikegulac sodium } & 1600 & Unpruned & $2.8 \mathrm{a}$ & $2.5 \mathrm{a}$ & $2.4 \mathrm{ab}$ & 0.0 \\
\hline & & $P$ value & 0.0001 & 0.0001 & 0.0001 & 0.0001 \\
\hline
\end{tabular}

${ }^{2}$ Treatments were applied on 12 June 2012.

${ }^{\mathrm{y}} \mathrm{l} \mathrm{ppm}=1 \mathrm{mg} \cdot \mathrm{L}^{-1}$

${ }^{x}$ Branching treatment: dikegulac sodium was applied to either pruned (hand-pruned, leaving three nodes) or unpruned plants.

"Assessed visually: $0=$ no injury, $10=$ complete kill.

${ }^{v}$ Means with the same letters within columns are not statistically different according to Tukey-Kramer studentized range test, $\alpha=0.05$

hand-pruned and untreated controls. These results from MS were similar to previous findings by Hester et al. (2013); they reported $74.4(279 \%)$ and $76.7(287 \%)$ more branches for
'Limelight' hydrangea grown under full sun during the 2011 growing season following application of dikegulac sodium (800 and $1600 \mathrm{ppm}$ ) to unpruned plants compared with the pinched control. Similarities between the two experiments were average temperatures; in 2011 average temperatures for $\mathrm{TN}$ were $29.7 / 17.2^{\circ} \mathrm{C}$ (day/night), which were similar to 
average day and night temperatures reported for MS in this study.

Previous reports indicate that plants grown under high temperature and light conditions require higher rates of PGRs (Whipker, 2013); however, our results do not fully support this. Although our objective was not to test the effects of temperature and light, our data indicate that high temperatures did not decrease the efficacy of dikegulac sodium applied to 'Limelight' because plants in MS were exposed to higher temperatures and had a greater branching response following treatment. However, plants at two locations were grown under different light levels ( $\mathrm{TN}=$ full sun; $\mathrm{MS}=40 \%$ shade $)$ and Dasoju et al. (1998) reported greater PGR efficacy (percent reduction in plant diameter) following rates $(4,8,16$, and $32 \mathrm{mg})$ of paclobutrazol application to plants grown in a greenhouse under natural daylengths in the winter months $\left[24 / 18^{\circ} \mathrm{C}\right.$ (day/ night) set point temperatures, average light levels $250 \mu \mathrm{mol} \cdot \mathrm{m}^{-2} \cdot \mathrm{s}^{-1}$ ] compared with plants grown in the summer months $\left[24 / 18{ }^{\circ} \mathrm{C}\right.$ (day/ night) set point temperatures (temperature did exceed the daytime set point) average light levels $550 \mu \mathrm{mol} \cdot \mathrm{m}^{-2} \cdot \mathrm{s}^{-1}$ ]. Even though, Dasoju et al. (1998) reported that summer temperatures exceeded the upper set point on some occasions, light was a contributing factor; therefore, we cannot rule out light as a potential contributing factor for the difference in the magnitude of branching response reported for the two locations.

For decades, surveys have indicated consumers prefer to buy quality plants (Padgett, 1961). However, "quality" is a subjective term and perception of quality based on attributes has varied in most consumer preference studies: size of plant (chosen from pictures) (Padgett 1961); healthy plants (deemed by color, roots, and shape) (Day, 1994); a healthy, bushy plant (Townsley-Brascamp and Marr, 1995); foliage on lower branches, healthiness, full, dense foliage, and symmetry (Glasgow et al., 1998); and evidence of new growth and absence of discolored or damaged foliage (Brand and Leonard, 2001). In our study, we used branch symmetry as a measure of plant quality (plant size, density, and branch symmetry). Pruning by hand or using a chemical pinching agent releases apical dominance, promoting lateral growth. This was evident in our study with improved branch symmetry following all treatments compared with untreated plants at both locations, with the exception of the hand-pruned and low rate of dikegulac sodium (400 ppm) applied to unpruned plants grown in $\mathrm{TN}$. In $\mathrm{TN}$, the lack of improved branch symmetry with no increase in branch number following hand pruning or the low rate of dikegulac sodium (400 ppm) to unpruned plants suggests 400 ppm was an inadequate rate to release apical dominance in plants grown in full sun. Moreover, hand-pruned plants and unpruned plants treated with $400 \mathrm{ppm}$ dikegulac sodium grown in MS had only $13 \%(P=0.01)$ improved branch symmetry over the untreated plants compared with at least $35 \%(P=$ $0.001)$ greater symmetry in all other treatments, respectively. With the modest improvement in branch symmetry coupled with low branch number among the hand-pruned control plants, the $400 \mathrm{ppm}$ rate for pruned plants and the $400 \mathrm{ppm}$ rate for unpruned plants suggest the lower rates were not as effective as the higher rates. Higher rates of dikegulac sodium appeared to initiate axillary budbreak by releasing apical dominance and promoting more lateral growth. Hand pruning alone was not a highly effective treatment for increasing quality or branch number.

Pruned plants treated with dikegulac sodium tended to have fewer flowers than unpruned plants treated with dikegulac sodium. Moreover, 800 or $1600 \mathrm{ppm}$ dikegulac sodium applied to unpruned plants grown in MS resulted in more flowers than untreated plants, but flowers were considerably smaller than those on untreated plants. These results were similar to previous reports by Cochran and Fulcher (2013) indicating unpruned Little Lime ${ }^{\mathrm{TM}}$ hardy hydrangea had smaller flowers following 1600 ppm dikegulac sodium compared with untreated plants. Additionally, floral indices of untreated and unpruned plants treated with $400 \mathrm{ppm}$ were greater than these of hand-pruned and dikegulac sodium (pruned and unpruned) treated plants at both locations, with the exception of handpruned plants grown in MS. In a recent survey, retail consumers preferred numerous smaller hardy hydrangea flowers to fewer but larger flowers (A. Fulcher, unpublished data).

Symptoms of phytotoxicity are known to be an issue with dikegulac sodium application (Banko and Stefani, 1996). This was evident in our study with chlorotic new growth on PGRtreated plants at 2 (TN and MS) and 6 (TN) WAT, which was similar to previous reports by Sansberro et al. (2006). They indicated chlorosis on new growth following application of dikegulac sodium to yerba mate (Ilex paraguariensis). By 6 WAT there was no visible phytotoxicity on plants in MS and by the end of the experiment at 18 WAT (a typical production period for 3-gal hardy hydrangea), no phytotoxicity was detected on plants in TN.

While our results were similar between the two locations, plants grown in TN had fewer branches and flowers develop compared with plants in MS, which tended to have magnified results in terms of greater branching, floral attributes, and reduced phytotoxicity, possibly due to shading. Hester et al. (2013) reported 'Merritt Supreme' and 'Nikko Blue' florist hydrangea and 'Limelight' hardy hydrangea varied in their responses to PGRs and location. For example, 'Merritt Supreme' treated with benzyladenine $(600 \mathrm{ppm})$ grown in MS and North Carolina had similar branch number to the pinched controls; whereas, in California, plants had more branches compared with the pinched controls. Furthermore, 'Nikko Blue' grown in Georgia treated with dikegulac sodium (800 or $1600 \mathrm{ppm}$ ), benzyladenine (300 or $600 \mathrm{ppm})$, and ethephon $(500$ or $1000 \mathrm{ppm})$ had similar branching to the pinched control; whereas, 'Nikko Blue' grown in Alabama treated with dikegulac sodium (800 or $1600 \mathrm{ppm})$, benzyladenine ( 300 or $600 \mathrm{ppm}$ ), and ethephon (500 and $1000 \mathrm{ppm}$ ) had fewer branches than the pinched control. Moreover, 'Merritt Supreme' and 'Limelight' treated with dikegulac sodium ( $800 \mathrm{ppm})$ had more branches than the pinched controls, regardless of location; whereas, 'Nikko Blue' had similar (Georgia) or fewer branches (Alabama) following application. Our data and the aforementioned data are in line with previous reports that species, environmental conditions, plant stress, substrates, irrigation regimes, and cultural practices can affect PGR efficacy (Bailey and Clark, 1992; Currey and 
Erwin, 2012; Keever, 2003; Keever and Olive, 1994; Kessler and Keever, 2008), reiterating the importance of growers testing PGRs on specific cultivars at their specific location.

Hand pruning, the industry standard to increase branching, was not effective at increasing branch number or substantially increasing plant quality. Likewise, applying dikegulac sodium to pruned plants vs. unpruned plants did not have an additive effect on 'Limelight' hydrangea, but did negatively affect floral attributes. Based on our results, growers can maximize branch number by applying dikegulac sodium $(800 \mathrm{ppm})$ to unpruned plants. However, growers should rely on data from their geographical area and not necessarily expect the same results from a different location.

\section{Literature cited}

Abdelgadir, H.A., A.K. Jäger, S.D. Johnson, and J. van Staden. 2010. Influence of plant growth regulators on flowering, fruiting, seed oil content, and oil quality of Jatropha curcas. S. Afr. J. Bot. 76:440-446.

Auer, C.A., J.D. Cohen, M. Laloue, and T.J. Cooke. 1992. Comparison of benzyl adenine metabolism in two Petunia bybrida lines differing in shoot organogenesis. Plant Physiol. 98:1035-1041.

Bailey, D.A. and B. Clark. 1992. Summer applications of plant growth retardants affect spring forcing hydrangeas. HortTechnology 2:213-216.

Banko, T.J. and M.A. Stefani. 1996. Growth response of large, established shrubs to Cutless, Atrimmec, and Trimcut. J. Environ. Hort. 14:177-181.

Brand, M.H. and R.L. Leonard. 2001. Consumer product and service preferences related to landscape retailing. HortScience 36:1111-1116.

Cathey, H.M., G.L. Steffens, N.W. Stuart, and R.H. Zimmerman. 1966. Chemical pruning of plants. Science 153:13821383.

Cochran, D.R. and A. Fulcher. 2013. Type and rate of plant growth regulator influences vegetative, floral growth, and quality of Little Lime ${ }^{\mathrm{TM}}$ hydrangea. HortTechnology 23:306-311.
Cohen, M.A. 1978. Influence of dikegulacsodium, Off-Shoot-O and manual pinching on rhododendrons. Sci. Hort. 8: 163-167.

Currey, C.J. and J.E. Erwin. 2012. Foliar applications of plant growth regulators affect stem elongation and branching of 11 kalanchoe species. HortTechnology 22:338-344.

Dasoju, S., M.R. Evans, and B.E. Whipker. 1998. Paclobutrazol drenches control growth of potted sunflowers. HortTechnology 8:235-237.

Day, E. 1994. An exploratory study of garden center selection for landscape plants. J. Environ. Hort. 12:142-146.

Glasgow, T.E. 1999. Consumer perceptions of plant quality. North Carolina State Univ., Raleigh, PhD Diss.

Glasgow, T.E., T.E. Bilderback, T. Johnson, K.B. Perry, and C.D. Safley. 1998. Evaluating consumer perceptions of plant quality. Proc. Southern Nursery Assn. Res. Conf. 43:497-500.

Hammond, H.E., R.K. Schoellhorn, S.B. Wilson, and J.G. Norcini. 2007. Differing blanketflower cultivar and ecotype responses to plant growth regulators. HortTechnology 17:552-556.

Hester, K.A., G. Bi, M.A. Czarnota, A. Fulcher, G.J. Keever, J.H. Lieth, J.D. Orsi, B.E. Whipker, K. Sullivan, and C.L. Palmer. 2013. Impact of Augeo, Configure and Florel on hydrangea branching. J. Environ. Hort. 31:27-29.

Holland, A.S., G.J. Keever, J.R. Kessler, and F. Dane. 2007. Single cyclanilide applications promote branching of woody ornamentals. J. Environ. Hort. 25:139144.

IR-4 Project. 2012. Ornamental horticulture: Plant growth regulator protocol 12013. 8 Aug. 2013. <http://ir4.rutgers.edu/ ornamental/ORNDrafts/12-013_Woody Branching.pdf $>$.

Keever, G.J. 2003. Plant growth regulation in ornamental nurseries - Unrealized opportunities. Plant Growth Regulat. Soc. Amer. Proc., 13th Annu. Mtg. p. 89.

Keever, G.J. and J.W. Olive. 1994. Response of 'Prize' azalea to Sumagic applied at several stages of shoot apex development. J. Environ. Hort. 12:12-15.
Kessler, J.R. and G.J. Keever. 2008. Plant growth retardants affect growth and flowering of Achillea $\times$ 'Coronation Gold'. J. Environ. Hort. 26:24-28.

Leib, B. 2012. Biosystems engineering and soil science: Selected weather data. 18 Mar. 2013. <http://bioengr.ag.utk. edu/weather/ $>$.

National Oceanic and Atmospheric Administration. 2012. 13 Feb. 2013. <http://www.ncdc.noaa.gov/cdo-web/ datasets/GHCND/stations/GHCND: USC00222094/detail>.

Norcini, J.G., J.H. Aldrich, and J.M. McDowell. 1994. Flowering response of Bougainvillea cultivars to dikegulac. HortScience 29:282-284.

Padgett, J.H. 1961. Economic analysis of the consumer market for woody ornamentals. Georgia Agr. Expt. Sta. Mimeo Ser. 108:1-28.

Sansberro, P., L. Mroginski, and R. Bottini. 2006. Stimulation of lateral branch formation on Ilex paraguariensis (Aquifoliaceae) seedlings. Aust. J. Exp. Agr. 46: 707-710

Starman, T.W. 1991. Response of Kientzler new guinea impatiens to manual and chemical pinching. HortScience 26:856857.

Townsley-Brascamp, W. and N.E. Marr. 1995. Evaluation and analysis of consumer preferences for outdoor ornamental plants. Acta Hort. 391:199-206.

U.S. Department of Agriculture. 2009. 2009 Census of horticultural specialties. 5 Jan. 2013. <http://www.agcensus. usda.gov/Publications/2007/Online_ Highlights/Census_of_Horticulture_ Specialties/hortic_1_023_023.pdf $>$.

U.S. Department of Agriculture. 2012. Plant hardiness zone map. 8 Aug. 2013. $<$ http://planthardiness.ars.usda.gov/ PHZMWeb/InteractiveMap.aspx>.

U.S. National Arboretum. 2005. What type of hydrangeas are available? 12 Feb. 2013. <http://www.usna.usda.gov/ Gardens/faqs/hydrangeafaq2.html>.

Whipker, B.E. 2013. Grower Talks: Plant growth regulator guide. 18 Feb. 2013. <http://www.ballpublishing.com/pdf/ PGR_GUIDE_2013-LowRez.pdf>. 